\title{
Interactive comment on "Detection of Outflow of Formaldehyde and Glyoxal from the African continent to the Atlantic Ocean with a MAX-DOAS Instrument" by Lisa K. Behrens et al.
}

\section{Lisa K. Behrens et al.}

Ibehrens@iup.physik.uni-bremen.de

Received and published: 6 June 2019

The comment was uploaded in the form of a supplement:

https://www.atmos-chem-phys-discuss.net/acp-2018-1286/acp-2018-1286-AC1-

supplement.pdf

Interactive comment on Atmos. Chem. Phys. Discuss., https://doi.org/10.5194/acp-2018-1286, 2019. 